\title{
Reactive Power Compensation in a Hybrid Renewable Energy System through Fuzzy Based Boost Converter
}

\author{
Sathish Ch. ${ }^{1}$, Chidambram I.A., ${ }^{1}$ Manikandan.M. ${ }^{2}$ \\ ${ }^{1}$ Annamalai University, India \\ ${ }^{2}$ Jyothishmathi Institute of Technology and Science, India
}

\begin{abstract}
The reactive power compensation is essential during hybrid grid connected system, because the overall power factor of the power systems is reduced due to DC energy fed to the grid using electronic energy inverters. Increased load on the grid due to poor power factor triggers losses in the grid. The main objective of the work related to control the Reactive Power flow in grid connected Hybrid Renewable Energy System (PV-wind-battery). The objectives of the work were achieved by satisfying the load demand, injecting the reactive power from hybrid sources to the grid. First, the proposed technique with fuzzy based boost converter is implemented. It reduced power conversion stages, decreases the losses compared to existing Hybrid Grid-connected systems. The most significant result of the work is the conclusion that the fuzzy based boost converter should increase the Maximum power from solar PV Panel, The speed control of wind energy system is control by speed controller-fuzzy rule, and it created with low speed to high speed. The significance of the obtained results is that the used methodology allowed maximum energy utilized by hybrid renewable energy system to grid.

The reactive power is maintained at zero level in order to ensure the unity power factor operation. But rather significantly enhances the small voltage fluctuation in the grid. In addition, to reduces the current total harmonic distortion to $1.9 \%$, which is good lower than the requirement for network operation. The proposed method is verified using MATLAB/Simulink. The simulation results were supported experimentally.
\end{abstract}

Keywords: hybrid renewable energy system, photovoltaic system, fuzzy based boost converter, total harmonic distortion.

DOI: https://doi.org/10.52254/1857-0070.2022.1-53.02

UDC: 611.3

\section{Compensarea puterii reactive într-un sistem hibrid de energie regenerabilă prin intermediul unui fuzzy convertizor de suport \\ Sathish Ch. ${ }^{1}$, Chidambram I. A. ${ }^{1}$, Manikandan.M ${ }^{2}$ \\ ${ }^{1}$ Annamalai Universitatea, ${ }^{2}$ Jyothishmathi Institutulde TechnologieșiȘtiința, India}

Rezumat. Scopul cercetării este de a îmbunătăți precizia localizării defectelor în izolație și determinarea tipului defectelor. Obiectivul este atins prin rezolvarea problemei de combinare a metodelor de contact și la distanță pentru izolatori din polimer și porțelan folosind descărcările parțiale (DP) model. Cele mai semnificative rezultate sunt legitățile obținute ale dinamicii caracteristicilor DP până la situația de pre-străpungere pentru izolatorii de porțelan, investigarea distribuției statistice a DP în funcție de intensitatea lor și identificarea particularităților distribuției statistice a descărcărilor de suprafață. O parte din lucrare este dedicată studierii caracteristicilor DP și a surselor lor după spectre, polaritate, distribuții statistice, oscilograme, importanța fiind din considerente de automatizare la depistarea DP interioare și de tipul arcului electric, de asemenea, pentru depistarea izolatoarelor din porțelan deteriorate de DP. Astfel, au fost determinate: semnele de defecțiune ale unui decalaj model semnalmentele de străpungere a intervalului de descărcare model, valoarea tensiunii de străpungere pentru izolatorul de porțelan defectat și cel funcțional, care pot fi utilizate pentru învățarea modelelor de rețele neuronale artificiale și pentru a depista în baza acestora anterioară defectării pe baza acestora. Relevanța rezultatelor constă în faptul, că în baza caracteristicilor DP se identifică izolatorii din polimeri, fiind umectați umeziți, inclusiv printre izolatorii de porțelan umectați. Cele mai semnificative rezultate sunt: evaluarea rezistenței ohmice a izolatorilor de porțelan în baza caracteristicilor DP, depistarea DP de tipul arc electric, interioare și de suprafață ale izolatorilor din polimeri, localizarea defectelor folosind senzori de radiație electromagnetică din benzile UHF și HF.

Cuvinte-cheie: sistemul hibrid de energie regenerabilă, sistem fotoelectric, convertizor de amplificare bazat pe fuzzy, distorsiuni armonice totale. 


\section{Компенсация реактивной мощности в гибридной системе возобновляемой энергии с помощью поддерживающего преобразователя на нечеткой логике СатхишЧ., 1 Чидамбрам И.А. ${ }^{1}$, Маникандан М. ${ }^{2}$}

${ }^{1}$ Университет Аннамалай, ${ }^{2}$ Институт технологии и науки Джйотишматхи, Индия

Аннотация. Компенсация реактивной мощности имеет важное значение в гибридной системе, подключенной к сети, поскольку общий коэффициент мощности энергосистем снижается из-за энергии постоянного тока, подаваемой в сеть с использованием электронных инверторов энергии. Увеличение нагрузки на сеть из-за низкого коэффициента мощности приводит к потерям в сети. Основная цель работы связана с управлением потоком реактивной мощности в подключенной к сети гибридной системе возобновляемой энергии (PV-ветер-батарея). Цели работы были достигнуты за счет согласования источников энергии с нагрузкой, подачи реактивной мощности от гибридных источников в сеть. Вопервых, реализуется предлагаемая методика с нечетким повышающим преобразователем. Это уменьшило количество стадий преобразования энергии, уменьшило потери по сравнению с существующими системами, подключенными к гибридной сети. Значение нашей работы состоит в том, для того, чтобы повысить низкое постоянное напряжение, создаваемое фотоэлектрической панелью, используется повышающий преобразователь с высоким коэффициентом усиления. Устройство накопления энергии помогает избежать колебаний мощности, вызванных прерывистыми источниками, такими как фотоэлектрические и ветровые, тем самым обеспечивая бесперебойную подачу в сеть. При использовании трехфазного инвертора с ПИ-регулированием полная мощность, производимая источником энергии, безопасно подается в трехфазную сеть. Новый узел состоит из нелинейного контроллера, модулируемого напряжением сети, и обычного контроллера. Предложенный метод проверен с использованием MATLAB/Simulink. Наиболее важные результаты при различных входных напряжениях показывают, что предложенный метод не только имеет хорошие характеристики слежения за активной и реактивной мощностью, но также снижает общее гармоническое искажение тока до 1,9 \%, что значительно ниже требований для работы сети.

Ключевые слова: гибридная система возобновляемой энергии, фотоэлектрическая система, повышающий преобразователь на нечеткой основе, полные гармонические искажения.

\section{INTRODUCTION}

The fundamental reason for shifting to renewable energy source (RES) is the hampering of industrial growth and economic status of the nation due to energy crisis. Due to industrial revolution, the demand for electrical energy has been steadily increasing. Moreover, the use of conventional fossil fuel technology has negative impact on the environment due to the emission of $\mathrm{CO}_{2}$ and greenhouse gases. Therefore, the focus has been turned to RES like wind, solar, biomass, hydro power, etc. Among all, solar and wind energy are the common renewable energy sources that are readily utilized for power generation. The RES provide clean energy [1,2]. Anyhow, relying on a particular type of RES sometime fails to satisfy the grid power requirement. This is because, the RES are not always available to satisfy the energy demand because of the stochastic and inconsistent nature of solar insolation and wind speed.

Thus, the HRES is utilized in this work, which integrates different types of distributed energy resources (DER) to enhance the power production. Here, WECS, PV system and battery forms the hybrid energy generation system (HRES). The HRES satisfies the energy demand of the load with high reliability and low cost[3].
HRES has two operational modes that are stated as grid-tied mode and islanding mode, each having its own benefits and drawbacks. The islanding mode is beneficial in areas where grid connection is not possible and hence it aids in electrifying the areas where transmission lines are difficult to construct. The grid connected mode is utilized in this work, which is advantageous in areas where transmission lines are already in place and requires reliable supply, such as towns and cities [4]. Generally, solar energy is regarded as an important RES due to its wide availability, low cost and pollution-free nature. The technology that converts the energy from the sun into electricity using semiconductors is known as PV technology [5, 6]. The low level DC voltage produced by the PV is raised to a greater level before being fed into the grid. In many applications, a transformer is utilized to boost voltage gain. However, the use of transformer has been limited as it is bulky and costly [7].

To enhance the energy produced by the PV and to connect PV to the utility grid, a high gain DC-DC converter has been utilized [8,9]. Therefore, a DC-DC boost converter with high voltage gain is developed in this work to enhance the low level DC voltage. 
However, the performance of the PV system is affected because of its intermittent behavior, instability and poor conversion ability. As a result, a DC/DC converter with an MPPT technique is required to ensure that the PV system produces the maximum amount of available power [10]. There are several power tracking methods are in practice to maximize the power produced by the PV panel. The power generated by the PV panel mainly depends on the solar insolation, cell temperature and load connected to it. These are all the factors that affect the productivity of the PV system. As a result, an efficient MPPT algorithm is used to achieve the highest level of productivity for PV frameworks. Initially, the classical MPPT techniques include Perturb and Observe (P\&O), Open circuit voltage (OCV), Hill climbing, Ripple correlation control (RCC), and Incremental conductance ( $\mathrm{InC})$ are considered. However, these MPPT approaches are ineffective because it cause peak overshoot problem and oscillation in the output [11]-[14]. Therefore, to rectify these issues, an artificial intelligence (AI) based MPPT algorithm is utilized. There are several AI MPPT algorithms, in which, Fuzzy Logic Control (FLC) based MPPT algorithm is an attractive one, as it does not require machine knowledge for implementing the MPPT.

On the other hand, wind energy is the fast growing RES, which produce electricity by consuming wind energy [15]. Synchronous generators and Induction generators (IG) are the commonly used wind turbine generators. Induction generators are reliable, cost-effective, simple and robust and have high rotational speed, therefore, it is utilized in this work. In earlier days, for small capacity wind system, the wind turbine has been driven by constant speed IGs.

Utilization of this constant speed IGs are limited because of passive output limits $[16,17]$. After several years, DFIGs are considered to be a good option for achieving variable speeds. Moreover, it possess simple design and is inexpensive, thereby increasing the speed and efficiency of the wind energy system $[18,19]$. The energy storage device (ESD) is used to mitigate the power fluctuations caused by inconsistent RESs like solar and wind.

Therefore the purpose of the battery is to improvise the quality and balance of electrical power before it is delivered to the load [20].

In order to control the working of battery, the converter has to isolate. The isolation of DC converter having a problem with an isolated voltage is that there is no reference voltage. This leads to problems when we are mitigate voltage to the grid. These problems have not been previously considered in the literature and they are the subject of study in this article.

The novelty of the work, an optimized fuzzy logic controller based chopper, is implemented in hybrid renewable energy system. The grid connected non isolated DC-DC converter, reduced power conversion stages, decrees the losses compared to existing Hybrid Gridconnected systems. It generates the suitable control signal for the PWM generator, which generates desired PWM pulses to control the speed of the wind turbine. In addition to that, the fuzzy logic control technique is assists with solar PV system. Large gain boost converter with fuzzy algorithm is to enhance the power generation capacity of the PV system. In addition to that, a drive system with FLC Algorithm is introduced, which control the speed of wind energy system. The efficiency of gird-connected system is improved, it maintain unity power factor, good transient response and less THD.

\section{OBJECT, SUBJECT, AND METHODS FOR RESEARCH}

The main objective of this work is to design and develop a Hybrid Renewable energy model based on solar photovoltaic (PV) systems integrated with Wind Energy Conversion Systems (WECS) to generated and provide a stable and maximum power during different electrical behavior like voltage sags, dips, harmonic etc.

In the hybrid renewable energy system in Fig 1, the grid synchronization of renewable energy source applications like PV source and WECS is performed. Anyway, the resultant PV voltage is insignificant and generally gets influenced by the effects of climate variations including irradiation and temperature. Hence, a fuzzy based MPPT controller is adopted which is robust and does not demand information regarding the actual model. The DFIG based wind energy conversion system is utilized along with an isolated DC-DC converter and offers wide range of operation. Both the renewable sources are synchronized with a three-phase grid which performs reactive power compensation with the mitigation of harmonics. This results in efficient power transfer as well as improved power quality. 




Fig. 1. Hybrid Renewable Energy System.



Fig.2 General fuzzy model block diagram.

In this research work, three converters such as three switch dc-dc isolated boost converter, two switch dc-dc isolated boost converter and single switch dc-dc non-isolated boost converter are proposed for the application of solar PV conversion system. Fuzzy Logic Control (FLC) technique and Proportional and Integral (PI) control techniques are proposed for these three converters. Three switch isolated dc-dc boost converter is designed with minimum number of components. Fuzzy logic control and proportional and integral control techniques are used to control this converter. This converter produces $120 \mathrm{~V}$ in the output to input of $12 \mathrm{~V}$ in FLC control technique. This converter develops $115 \mathrm{~V}$ as output to the input of $12 \mathrm{~V}$.

Both control techniques produce low voltage stress across switches and low ripple. The fuzzy system provides the control signals to the power generation plants using a linguistic rule obtained from the source. It can be used to design the control system using linguistic information for providing accurate details without actual source values.

The factor to be considered in fuzzy logic is fine tuning in order to obtain the desired signal.Fig.2 depicts the general fuzzy model block diagram, where the input is processed in the fuzzy controller using a rule based engine, and then defuzzification is performed results into the final output. In this model, the hybrid inverter is used to provide the output voltage based on the grid reference voltage.

\section{Algorithm: 1: \\ Drive system with FLC Algorithm}

The proposed fuzzy logic speed controller participation for non isolated DC-DC converter fed wind energy hybrid system shown in Fig. 3. 
Here, $\left(\Delta \omega_{r}\right)$ is the speed error between the set speed (reference speed-N ref) and rotor shaft speed $(\mathrm{N})$ is used to produce the following inputs to the controller;

$$
\begin{aligned}
& u=k_{i}\left(\Delta \omega_{r}\right) u=k_{\mathrm{P}} \Delta \omega_{r} \\
& u=k_{\mathrm{P}} \int\left(\Delta \omega_{r}\right) d t
\end{aligned}
$$

By proper adjustment of the member functions and the gains $k_{\mathrm{p}}, k_{i}$.

The controller realizes a nonlinear control algorithm. The output is a torque reference, $T_{e m}^{*}$

For meeting the desired speed tracking action of the drive. For the Fuzzification progress in the FLC, the membership functions crisp inputs $u_{1}, u_{2}$. It converted into fuzzy subsets. Then the input membership functions are related with crisp inputs and form the triangular, while increasing width of the triangular control action is fixed near the set point. The control functions are framed through linguistic variables. The proposed FLC linguistic variables for the speed control are classified into five groups.

They are namely Negative Large ( $N L)$, Negative Small ( $N S$ ), Zero ( $Z E$ ), Positive Large ( $P L)$, and Positive Small (PS). The Table.1 shows the proposed speed controller-fuzzy rule set table. The rule set is created with low speed to high speed.

Table.1 FLC, fuzzy rule set table.

\begin{tabular}{|c|c|c|c|c|c|}
\hline$\frac{e}{\Delta e}$ & $N L$ & $N S$ & $Z$ & $P S$ & $P L$ \\
\hline$N L$ & $Z E$ & $P S$ & $N S$ & $N L$ & $P L$ \\
\hline$N S$ & $N S$ & $Z$ & $P L$ & $N S$ & $P S$ \\
\hline$Z E$ & $N L$ & $P S$ & $Z E$ & $N S$ & $P L$ \\
\hline$P S$ & $N S$ & $N L$ & $P L$ & $Z E$ & $P S$ \\
\hline$P L$ & $P L$ & $N S$ & $P S$ & $N L$ & $Z E$ \\
\hline
\end{tabular}

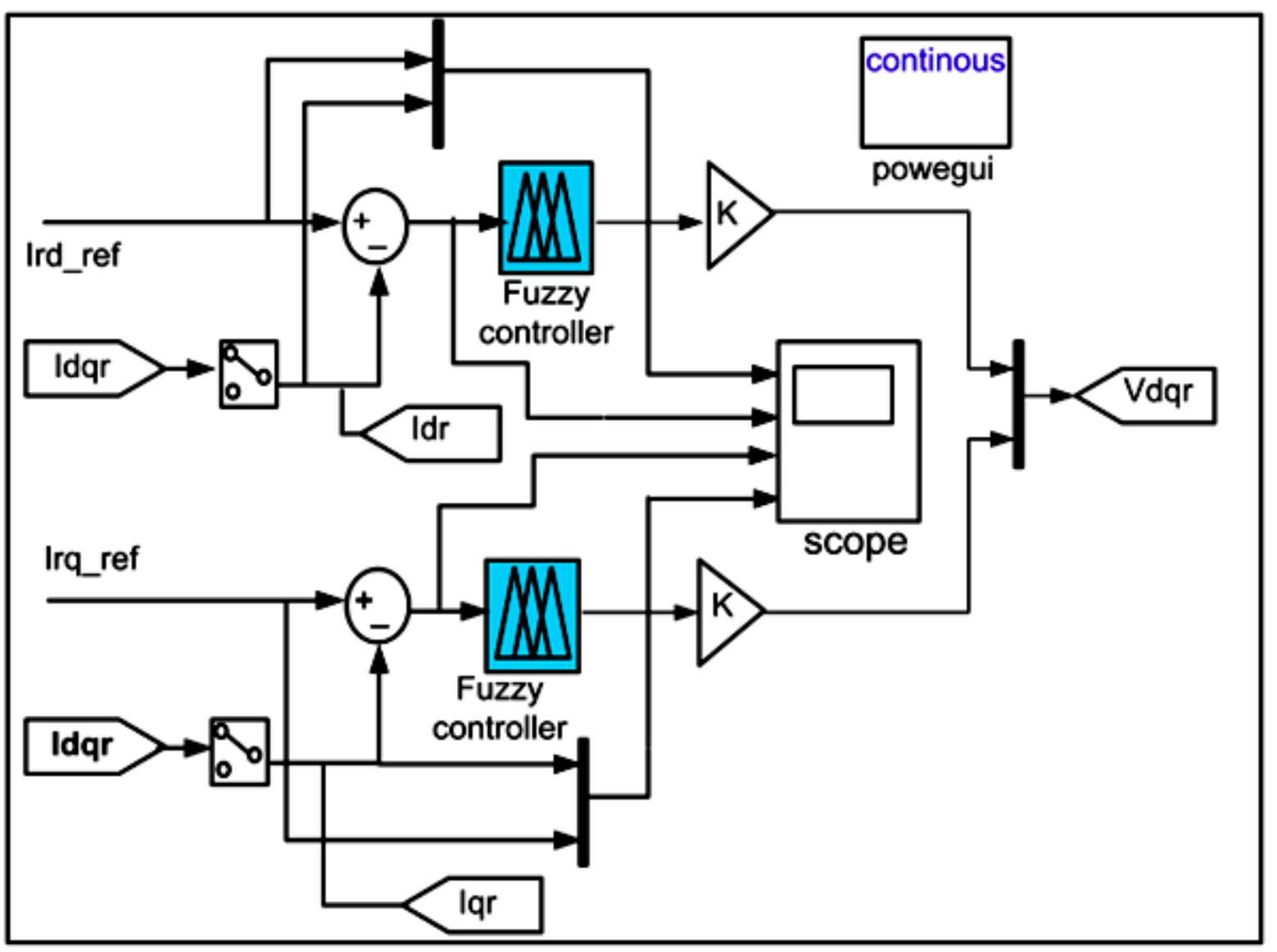

Fig.3.Control signal for non-isolated DC-DC converter fed wind energy hybrid system. 


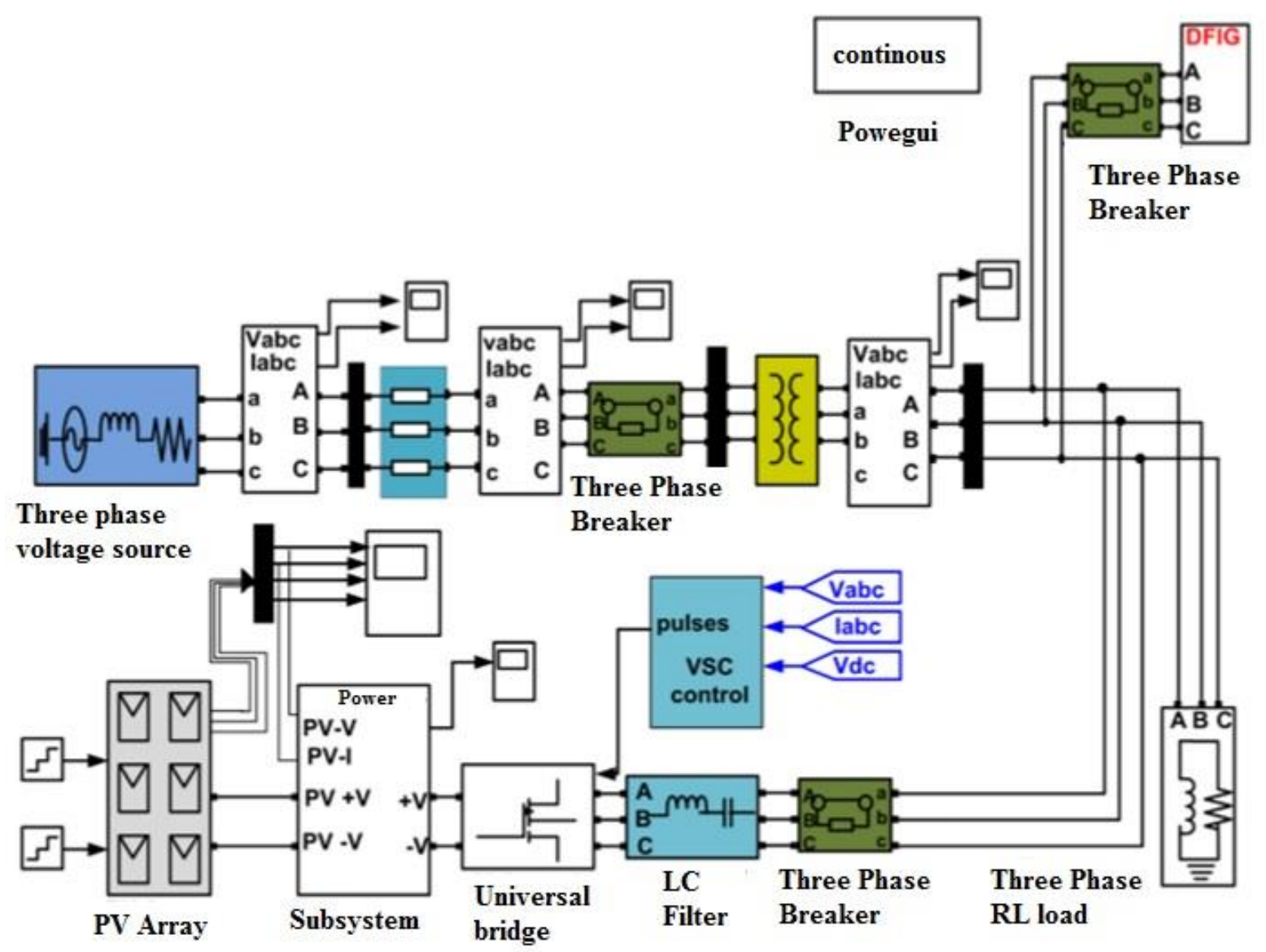

Fig.4. A simulation model of hybrid PV / DFIG based grid integration system using fuzzy controller.

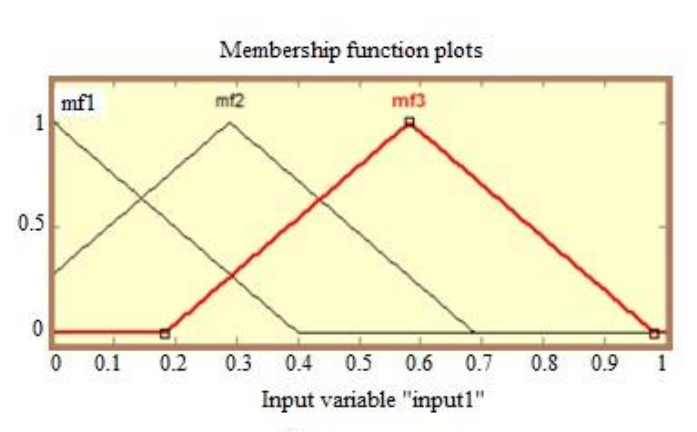

(a)

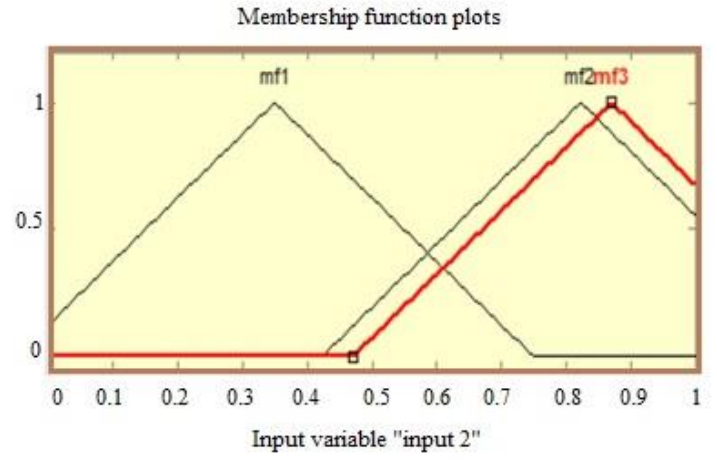

(b)

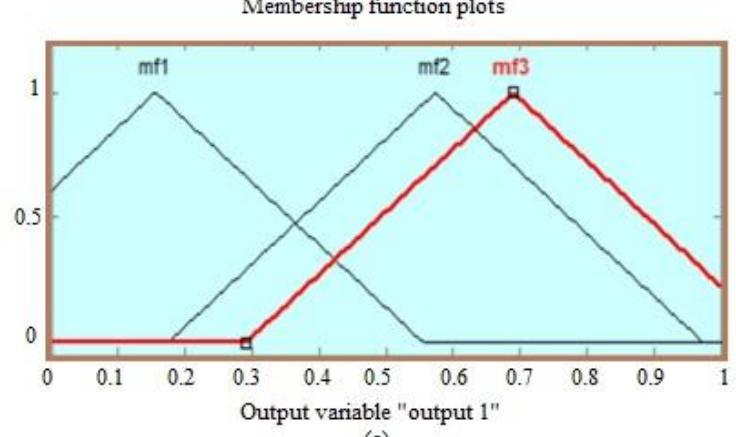

(c)

Fig. 5.(a) Membership function plot- Input variable 1(b) Membership function plot- Input variable 2 (c) Membership function plot- Output Variable. 


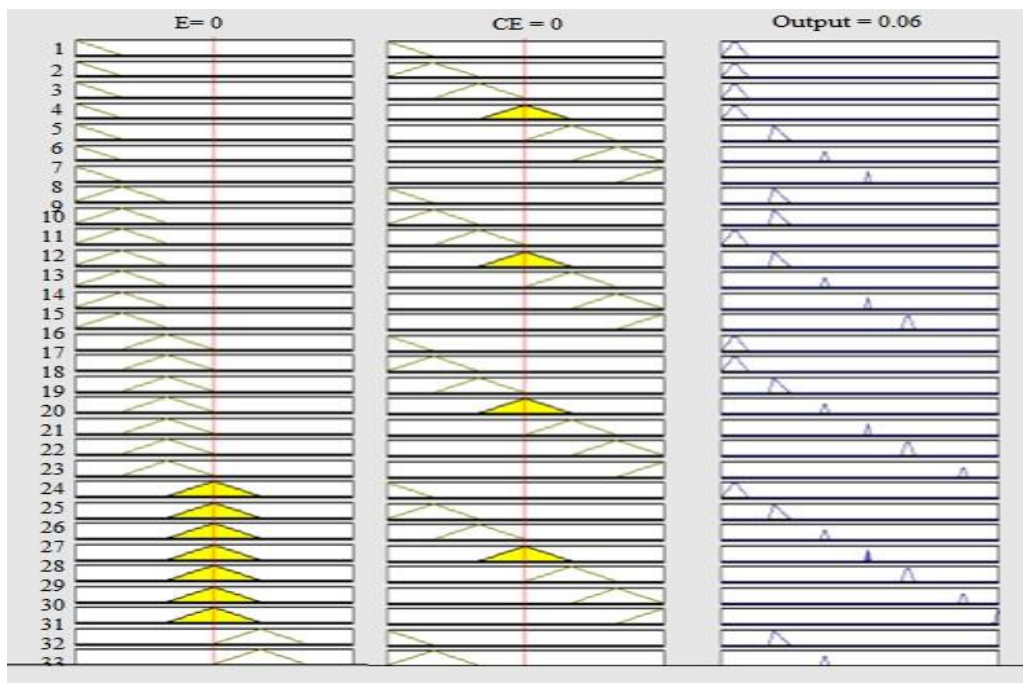

Fig.6. Fuzzy rules view.

The knowledge base table (truth table) consists of 25 rules for calculating the result of the fuzzy implication practice, as presented in the Table 1. The fuzzy set table values are relating with membership functions and the results are given to the fussy Inference Engine (IE).

Inference Engine (IE) reproduces the human analysis (trained logic) through constructing fuzzy inference inputs and IF-THEN rules. After the Defuzzification process the desired reference values is given to the control, which minimize the speed error. Defuzzification is the process of producing inputs into one output. In these two inputs are used. They are, Error (e) and Changes of error or change of speed error $w_{e}, \Delta_{e}$ respectively.

The proposed fuzzy logic speed control used Mamdani type inference engine, which is well suited for proposed controller than Sugeno type. The centroid method defuzzification strategy is used here to extract the set of output values. The Figure 5(a),5(b) and 5(c) shows the inputs (vaibale1 and 2) and output Mamdani inference engine maps. The inputs and output surface view mapping of the proposed FLC is given in Figure 6. Here the fuzzy sets are compared between the two input variables and it produces the essential gain to maintain generator speed.

\section{Algorithm:2 \\ Perturbation and Observe Algorithm}

This algorithm is based on an intentional and periodical perturbation on the control command with a following observation and evaluation of the system output. Applied to the PV system, the perturbation is generated through a change in the voltage and current. $V_{i n}(k), I_{i n}(k)$ respectively, such that the power of the PV is measured. This implies that the slope can be calculated, which helps with knowing whether the MPP is achieved, that is $\frac{\Delta_{p}}{\Delta_{v}}$ which is shown in fig.8.

Based on the previous description and on the detailed logic of Figure 8, the knowledge of $P_{\text {in }}(k)$ and $V_{\text {in }}(k)$ its delay in $k-1$ allows for the calculation of the mentioned slope. Therefore, if the latter mentioned value is positive, the duty cycle" $d$ " will increase such that the algorithm output $u=d+\Delta d$ and aims to reach the MPP; on the contrary, when theposition is at the right side of the MPP, the control signal decreases through $u=d+\Delta d$

\section{Sliding Mode Controller}

Considering that the error is defined as Eq (3), Where $V_{\text {ref }}$ is the reference voltage, then an integral sliding surface is established through Eq(4). such that, $\lambda \supset 0$.

$$
\begin{aligned}
& e=v_{r e f}-v_{i n} \\
s= & e-\lambda \int e . d t \\
u= & u_{e q}+u_{s w}
\end{aligned}
$$

The equation (5) is the control signal is composed of an equivalent control and switching control signal

That is, $u_{e q}$ and $u_{s w}$, respectively.

$$
u=d+\Delta d
$$






Fig.7. Flowchart of $\mathrm{P \& O}$ algorithm.



Fig.8.Power-Voltage curve with the P\&O mechanism to reach the MPP.

As previously mentioned, obtaining the equivalent control signal implies that the surface derivative should be equal to zero.

Therefore, as the error was formerly expressed in Equation (3), and with the usage of the system algorithm Flowchart depicted in .7. the equivalent control term is obtained as follows.

$$
u_{e q}=\frac{-1}{x_{2}}\left(v_{i n}+\lambda L e-x_{2}\right)
$$

The complete simulation model of hybrid PV and DFIG based wind energy system for the grid integration using fuzzy controller is presented in the fig.4. The synchronizing of renewable energy source into the power grid has many challenges such as to match two AC source voltage profile, frequency profile and phase angle.

\section{ANALYSIS OF THE MODEL AND THE METHODOLOGY OF ITS RESEARCH}

\section{A. PV coupled DC-DC Boost Converter with FLC}

Generally, the PV source is a current source relying on the incoming solar radiation and is called photo current. This solar radiation generates electron-hole pair and the electrons move to the $\mathrm{n}$-end and holes move to the $\mathrm{p}$-end due to the separation by the p-n junction. The electrodes collect the electrons and holes but few of them recombine before reaching the electrode. Due to this process, series resistance $R_{S}$ and parallel resistance $R_{P}$ occurs in the circuit.

The diode equation is expressed as, 


$$
I_{D}=I_{0}\left(e^{A V_{D}}-1\right)
$$

Where, $A=\frac{q}{\gamma k T_{e}}$ in which $q=$ electron charge

$\gamma=$ diode ideality factor

$k=$ Boltzmann constant

$T_{e}=$ absolute temperature

$I_{0}=$ diode saturation current

The current balance equation is given by,

$$
I_{p h}-I_{D}-I_{p}=I_{L}
$$

Substituting eq (1) in (2),

$$
I_{p h}-I_{0}\left(e^{A V_{D}}-1\right)-\frac{V_{D}}{R_{p}}=I_{L}
$$

Since,

$$
\begin{gathered}
V_{D}=V_{L}+I_{L} R_{S} \\
I_{p h}-I_{O}\left(e^{A V_{D}}-1\right)-\frac{V_{L}+I_{L} R_{S}}{R_{\rho}}=I_{L} \\
\frac{d I_{L}}{d_{t}}=\frac{V_{L}}{L} \\
\frac{d V_{0}}{d t}=-\frac{V_{0}}{R C}
\end{gathered}
$$

The state equations for the OFF condition of switch are expressed as,

$$
\begin{aligned}
& \frac{d I_{L}}{d t}=\frac{v_{L}}{L}-\frac{V_{0}}{L} \\
& \frac{d v_{0}}{d t}=\frac{I_{L}}{C}-\frac{V_{O}}{R C}
\end{aligned}
$$

It is a nonlinear control approach applied for tracking the maximal power point of the nonlinear features of the PV system. It has the ability to operate in conditions of uncertainty and does not rely on the actual system model. It also offers improved tracking as well as high robustness compared to other approaches

$$
e(t)=\frac{P(t)-P(t-1)}{I(t)-I(t-1)}
$$

Where, $P=V \times I$ the change in error is,

$$
d e(t)=e(t)-e(t-1)
$$

The inference engine performs fuzzification of input values for the determination of output values with the application of fuzzy rule base. The duty ratio is attained from defuzzification and is applied to the converter for controlling the gate pulse.

\section{B. DFIG based Wind Energy Conversion System}

The rotor circuit of the DFIG based WECS exploits back to back converters in which the rotor side assures the reactive power control of stator side. The WECS faces incremental change across the load which further results in minimal variations of system parameters. The minimal variation in real power relies on the system frequency and the incremental variation in reactive power does not depend on the voltage.

The DFIG generated reactive power is given by,

$$
Q_{D F I G}=\frac{L_{M}}{L_{S S}} V_{1} I_{d R}-\frac{V_{1}^{2}}{W_{S} L_{S S}}
$$

Equation (9) is rewritten as,

$$
\Delta Q_{D F I G}(S)=K_{f} \Delta I_{d R}(S)+\mathrm{K}_{e} \Delta v(s)
$$

where,

$$
K_{f}=\frac{L_{M} V_{1}}{L_{S S}}, K_{e}=\frac{L_{M} I_{d R}}{L_{S S}}-\frac{2 V_{1}}{W_{S} L_{S S}}
$$

The reference current in the output voltage loop obtained by the PI controller is given by,

$$
\Delta I_{d R}^{r e f}=\left(k_{p}+\frac{k_{1}}{s}\right)\left[\Delta v^{r e f}(s)-\Delta v(s)\right]
$$

\section{Bidirectional Isolated DC-DC Converter for Battery}

The converter comprises of two full bridge inverters, single isolation transformer as well as high frequency $\mathrm{AC}$ reactor that is connected across both ends of the transformer. The flow of current from the secondary part to the primary part is termed as charging and the flow of current from the primary part to the secondary part is termed as discharging. During charging, $L_{A}$ and $L_{B}$ perform zerovoltage switching with $C_{B A}-C_{B D}$ in the secondary part inverter as well as $L_{A}$ and $L_{B}$ functions as a boost reactor in the primary part. During discharging, $L_{A}$ and $L_{B}$ perform zero voltage switching with $C_{A A}-C_{A D}$ in the primary part inverter as well as $L_{A}$ and $L_{B}$ functions as a boost reactor in the secondary part. The duty cycle is given as $50 \%$ and the switching pattern of $Q_{A A}$ 
and $Q_{A B}$ is coordinated with $Q_{B A}$ and $Q_{B B}$. The dead time given by $\theta_{d t}$ is set to the switching time of every leg. The gating phases of $Q_{A A}$ and $Q_{A B}$ are constant and $Q_{A C}$ and $Q_{A D}$ are shifted by $\theta_{A}$ in the primary part. The gating phases of $Q_{B A}$ and $Q_{B B}$ are constant and $Q_{B C}$ and $Q_{B D}$ are shifted by $\theta_{B}$ in the secondary part in which $\theta_{A}$ and $\theta_{B}$ are dimensionless. Variations based on the relation between $V_{1} N_{2}$ and $V_{2} N_{1}$ occur in the switching conditions of $\theta_{A}$ or $\theta_{B}$ between charging and discharging.

When $\left.V_{1} N_{2}\right\rangle V_{2} N_{1}$, the excited term $T_{e c}$ is expressed as,

$$
T_{e c}=\left(\theta_{A}-\theta_{B}-\theta_{d t}\right) T
$$

The transmitted term $i_{t r B}$ is expressed as,

$$
T_{t t}=\left(1-2 \theta_{A}\right) \frac{T}{2}
$$

The dead time $T_{d t}$ s expressed as,

$$
T_{d t}=\theta_{d t} T
$$

Now, in $T_{e c}$ is given by,

$$
\left\{L_{B}+\left(\frac{N_{B}}{N_{A}}\right)^{2} L_{A}\right\} \frac{\left(I_{t r B B}-I_{t r B A}\right)}{\left(\theta_{A}-\theta_{B}-\theta_{d t}\right)}=V_{B}
$$

$i_{t r B}$ in $T_{t t}$ is given by,

$$
\left\{L_{B}+\left(\frac{N_{B}}{N_{A}}\right)^{2} L_{A}\right\} \frac{\left(I_{t r B B}+I_{t r B 0}\right)}{\left(\frac{1}{2}-\theta_{A}\right)}=V_{A}\left(\frac{N_{A}}{N_{B}}\right)-\mathrm{V}_{B}
$$

$i_{t r B}$ in $T_{d t}$ is given by,

$$
\left\{L_{B}+\left(\frac{N_{B}}{N_{A}}\right)^{2} L_{A}\right\} \frac{\left(I_{t r B 0}-I_{t r B A}\right)}{\theta_{d t} T}=V_{B}
$$

The charging/discharging power $P_{B}$ is given by,

$$
P_{B}=\frac{V_{A}\left(\frac{N_{B}}{N_{A}}\right) \mathrm{V}_{B}\left(\theta_{A}-3 \theta_{d t}\right)\left(\frac{1}{2}-\theta_{A}\right) T^{2}}{\left\{L_{B}+\left(\frac{N_{B}}{N_{A}}\right)^{2} L_{A}\right\}} f_{s w}
$$

When $\left.V_{1} N_{2}\right\rangle V_{2} N_{1}$, the excited term $T_{e c}$ is expressed as,

$$
T_{e c}=\left(\theta_{B}-\theta_{A}-\theta_{d t}\right) T
$$

The transmitted term $T_{t t}$ is expressed as,

$$
T_{t t}=\left(1-2 \theta_{B}\right) \frac{T}{2}
$$

The dead time $T_{d t}$ is expressed as,

$$
T_{d t}=\theta_{d t} \mathrm{~T}
$$

Now, $i_{t r B}$ in $T_{e c}$ is given by,

$$
\left\{L_{B}+\left(\frac{N_{B}}{N_{A}}\right)^{2} L_{A}\right\} \frac{\left(I_{t r B O}-I_{t r B A}\right)}{\theta_{d t} T}=V_{A}\left(\frac{N_{B}}{N_{A}}\right)
$$

$i_{t r B} \operatorname{In} T_{t t}$ is given by,

$$
\left\{L_{B}+\left(\frac{N_{B}}{N_{A}}\right)^{2} L_{A}\right\} \frac{\left(I_{t r B B}+I_{t r B 0}\right)}{\left(\frac{1}{2}-\theta_{A}\right)}=V_{B}-\mathrm{V}_{A}\left(\frac{N_{B}}{N_{A}}\right)
$$

$i_{t r B} \operatorname{In} T_{d t}$ is given by,

$$
\left\{L_{B}+\left(\frac{N_{B}}{N_{A}}\right)^{2} L_{A}\right\} \frac{\left(I_{t r B O}-I_{t r B A}\right)}{\theta_{d t} T}=V_{A}\left(\frac{N_{B}}{N_{A}}\right)
$$

The charging/discharging power $P_{B}$ is given by,

$$
P_{B}=\frac{V_{A}\left(\frac{N_{B}}{N_{A}}\right) \mathrm{V}_{B}\left(\theta_{B}-3 \theta_{d t}\right)\left(\frac{1}{2}-\theta_{B}\right) T^{2}}{\left\{L_{B}+\left(\frac{N_{B}}{N_{A}}\right)^{2} L_{A}\right\}} f_{s w}
$$

Equations (18) and (25) illustrate that the control of charging and discharging is performed by seamless adjustment in a single variable of phaseshift amount. The reference current for active power control is set by the outer dc-voltage control loop whereas the compensation of harmonics as well as reactive power is achieved by the inner current loop. In addition, the PI controller provides improved performance during the regulation of dc variables. Consider the voltages across the $3 \phi$ grid as,

$$
\begin{aligned}
& e_{A}=E \cos (\omega t), e_{B}=E \cos \left(\omega t-\frac{2 \pi}{3}\right), \\
& e_{c}=E \cos \left(\omega t+\frac{2 \pi}{3}\right)
\end{aligned}
$$


Here, $E$ : Maximum phase voltage, $\omega:$ Angular frequency.

The load currents are denoted as the algebraic sum of the inverter currents injected as well as the phase grid currents and are given by,

$$
i_{L A}=i_{g A}-i_{i n v A}, i_{L B}=i_{g B}-i_{i n v B}, i_{L C}=i_{g C}-i_{i n v C}
$$

where, inverter currents: $i_{\text {innA }} i_{\text {invB }}, i_{\text {invC }}$.

The equations for voltage related to $\mathrm{ABC}$ frame are given by,

$$
e_{A}=L \frac{d i_{A}}{d t}+v_{A}, \quad e_{B}=L \frac{d i_{B}}{d t}+v_{B}, \quad e_{c}=L \frac{d i_{c}}{d t}+v_{c}
$$

Where,

$$
\begin{aligned}
& e_{A}, e_{B}, e_{C}: \text { Voltages at grid side } \\
& V_{A}, V_{B}, V_{C}: \text { Voltages at terminals } \\
& L: \text { Coupling inductance }
\end{aligned}
$$

Converting (15) to synchronous $d-q$ reference frame,

$$
\begin{gathered}
e_{d}=L \frac{d i_{d}}{d t}-\omega L i_{q}+v_{d}, \\
e_{q}=L \frac{d i_{q}}{d t}-\omega L i_{d}+v_{q}
\end{gathered}
$$

\section{Simulation model of hybrid PV / DFIG based grid integration system using fuzzy controller.}

There are many renewable sources developed in electrical power engineering by utilization of natural resources for the generation of electrical power. The RES modules that can be used are PVA, wind farm, fuel cell, tidal energy farms, biogas plants, etc. Apart from all these sources, solar PV and wind farm RES modules are considered to be optimal options for the generation of power from renewable natural sources. These modules have less installation and less maintenance cost and hence are adopted into our proposed distribution test system. The internal modeling of solar PV along with fuzzy based boost converter topology can be considered for modelling. In addition to that, The PMSG wind farm is connected to the boost converter in parallel with the solar PV module. The PMSG produces three-phase variable voltage that varies with wind speed. A diode bridge rectifier is attached in parallel to the solar PV converter and converts the PMSG output to DC voltage.

Both the solar PV and PMSG wind farm are connected in parallel to a three-phase inverter which converts DC power to three-phase AC power which can be utilized by the loads or interconnected to a three-phase grid for power sharing. For grid interconnection, a three-phase voltage synchronization is needed for sharing of power from RES. The inverter is controlled by the three-phase sinusoidal PWM technique. The modeling diagram is shown in fig.4.

\section{RESUlTS \& DISCUSSIONS}

The grid tied HRES system with PV, WECS and energy storage device is investigated in this work.

For analysis of power transfers from each module and voltage magnitude at $\mathrm{PCC}$, simulations are run on three different test systems using the below modules. The system 1- hybrid with battery connected system feeding variable load, system 2Wind power generation with battery without PV power source grid with the renewable source connected in parallel and system 3- Solar with battery connected system. In all the above test systems same load variations are taken at different instants of time with different active and reactive power consumptions.

Table 2. PV panel parameter specification and boost converter ratings.

\begin{tabular}{|c|l|c|}
\hline S.no. & $\begin{array}{l}\text { Design } \\
\text { Parameters }\end{array}$ & Parameter Ratings \\
\hline 1 & Maximum Voltage & 65VDC \\
\hline 2 & Operating Current & $2 \mathrm{~A}$ \\
\hline 3 & Operating Voltage & $185 \mathrm{~V}$ \\
\hline 4 & Operating Power & $10 \mathrm{KW}$ \\
\hline 5 & No. of series cells & 36 \\
\hline 6 & Total No. of panels & 10 \\
\hline 7 & Area of each cell & $125 \mathrm{~mm} \times 31.25 \mathrm{~mm}$ \\
\hline 8 & $\begin{array}{l}\text { Range of } \\
\text { Temperature }\end{array}$ & -40 to $85 \mathrm{Degree} \mathrm{C}$ \\
\hline 9 & Capacitors C & $35 \mu \mathrm{F}$ \\
\hline 10 & Inductor $\mathrm{L}_{1}, \mathrm{~L}_{2}$ & $355 \mu \mathrm{H}$ \\
\hline 11 & Load Resistance $\mathrm{R}_{\mathrm{L}}$ & $10 \Omega$ \\
\hline 12 & $\begin{array}{l}\text { Switching } \\
\text { Frequency }\end{array}$ & $10 \mathrm{KHZ}$ \\
\hline
\end{tabular}

A high gain boost converter with fuzzy-MPPT algorithm is employed to enhance the power generation capacity of the PV system. A PWM rectifier is utilized for performing the AC to DC conversion in the DFIG based wind energy system. The rotational speed of the wind turbine is adjusted by assigning a traditional PI controller, which works by following the feedback control mechanism.

The excess energy produced by the wind and PV system is stored in a battery, thereby it provides 
uninterrupted supply to the grid when the renewable sources are not available. The battery charging and discharging has been controlled by an isolated DC-DC converter. Therefore, the energy produced by the HRES is safely injected into the three-phase grid through threephaseinverter. The PV panel parameter specification and boost converter ratings are listed in Table 2.

\section{A. Case-1 Hybrid with Battery Connected}

The PV output electrical energy and wind output electrical energy is represented in the following figures respectively.

It showed a constant output voltage due to the improved proposed MPPT technique.

The solar power output is constant through MPPT controller at constant DC voltage of about 64 volt as depicted in fig.9. and current maximum of 1.9A is shown in fig 10 .

The output voltage of Hybrid with Battery Connected (wind and solar) is shown in fig. 11. The standard technique can be boosted by means of inter-level converter output. MPPT signal waveform for Inter-leaved boost converter is shown in fig 12.

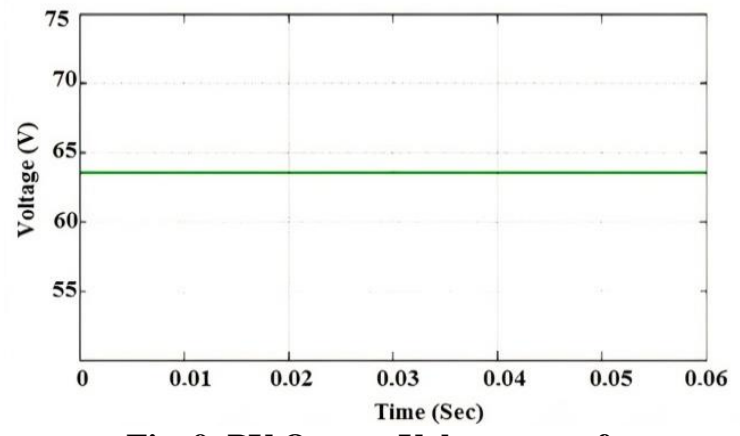

Fig. 9. PV Output Voltage waveform.

The generated Hybrid system output voltage is not used for commercial or domestic purpose.

However, the Inter-level boost converter will boost the output voltage up to the desired level that is 182voltage is increased and the voltage is maintained to about 600 volt DC that is depicted in Fig.8. and fig. 14.

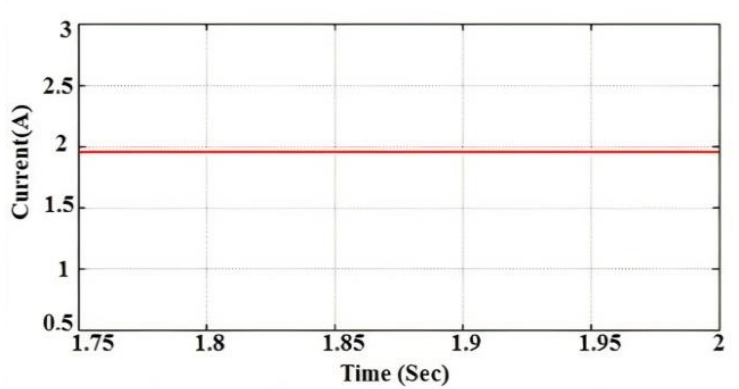

Fig.10. PV output current waveform.

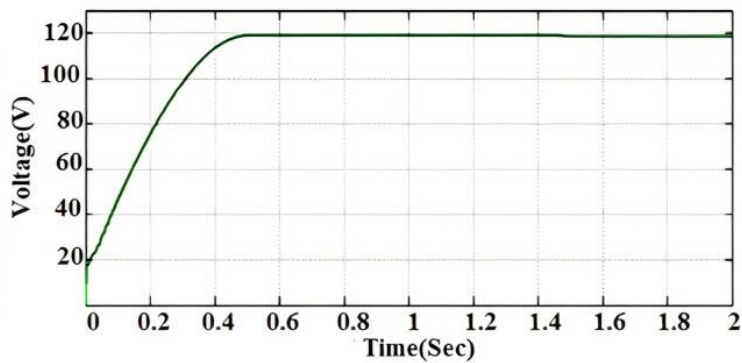

Fig.11.Wind System voltage waveform output.



Fig.12. MPPT signal waveform for Interleaved boost converter.

The boost up electrical signal is given to inverter which is provided with the PWM technique which is given to the simulated model semiconductor switch as shown in the Fig 15.

The final output AC voltage form inverter is generated and the electrical energy and current waveform is represented is given away in the fig 16 respectively.

The generated voltage waveform is reached 600 volt AC output which is exactly the output voltage of DC voltage output referring that nil switching and conduction losses.

The output current waveform rose to 100 amps due to the introduction of load consisting of resistive and reactive component.

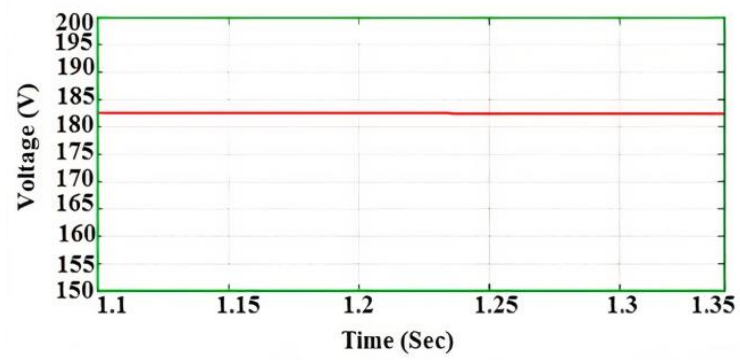

Fig.13.Constant DC link voltage. 


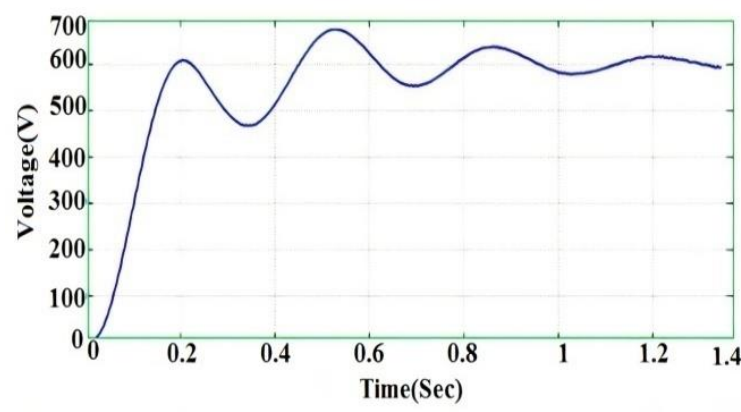

Fig.14.Interleaved boost converter output Voltage waveform.

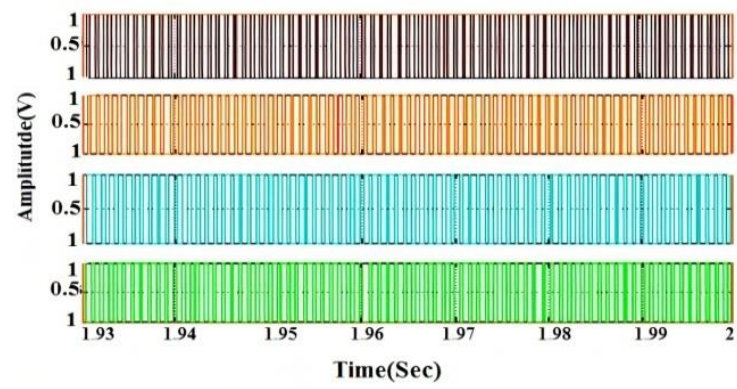

Fig.15.PWM signal waveform for Inverter control.

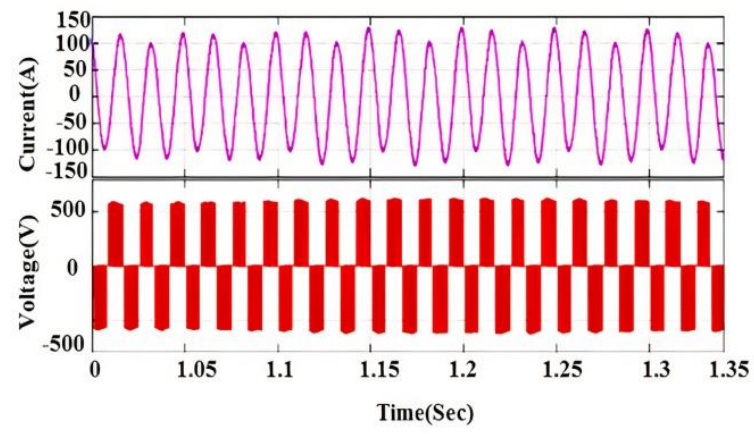

Fig.16. AC output Voltage - current waveform.

\section{B. Case II: Wind power generation With Battery without $P V$ power}

The wind power generation with battery module without solar power system connected to the micro grid.

The output power of DC waveform for wind power system module is exposed in fig. 17, the output current waveform shown in fig. 18

The inter-leaved boost converter output voltage waveform, AC output electrical energy are publicized in the fig 19 and fig.20 respectively.

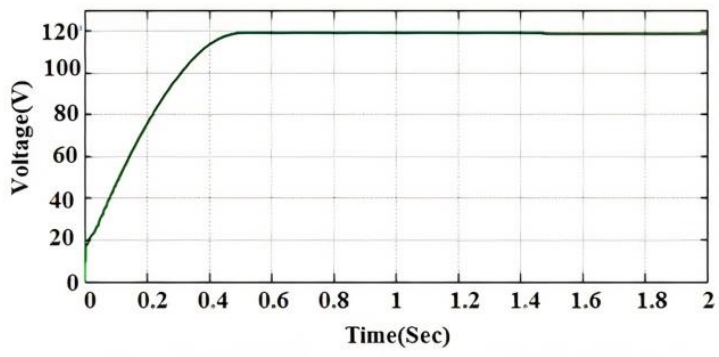

Fig.17 Wind power voltage waveform.



Fig.18 Wind output current waveform.

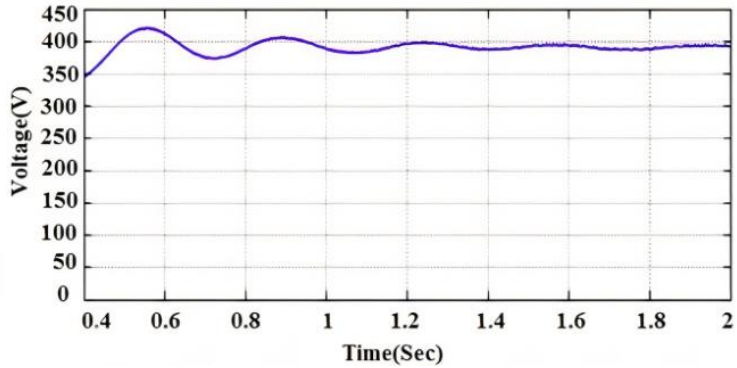

Fig.19 DC output boosted voltage waveform.

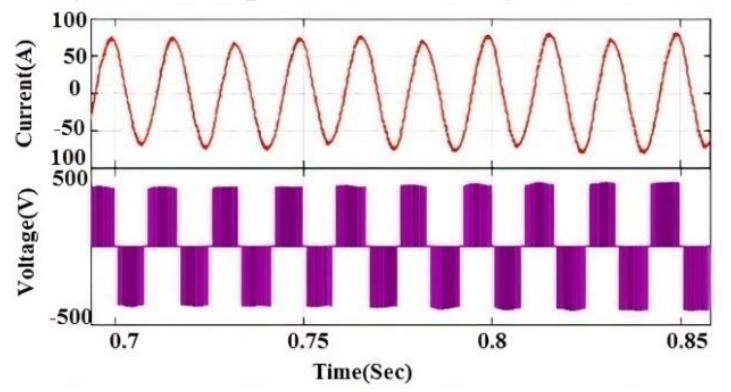

Fig.20 Output voltage waveform of AC.

\section{Case III: Solar with Battery Connected.}

The solar PV with Battery connected system voltage output waveform is made known in the fig 21 , the current output waveform is publicized in the fig 22 and The dc link voltage due to solar and battery connected is made known in the fig 23 .

The boosted output electrical energy waveform of PV with battery is exposed in the fig 24, and AC output electrical energy waveform is publicized in the fig 25 . Finally, the FFT analysis for interleaved boost converter fed inverter tied micro grid.

The total energy produced by the HRES system is fed in to the $3 \phi$ grid through an inverter.Thus the PI controller is assigned to control the operation of inverter by analogizing the real power with the reactive power, thereby safely inject the power into the grid. 


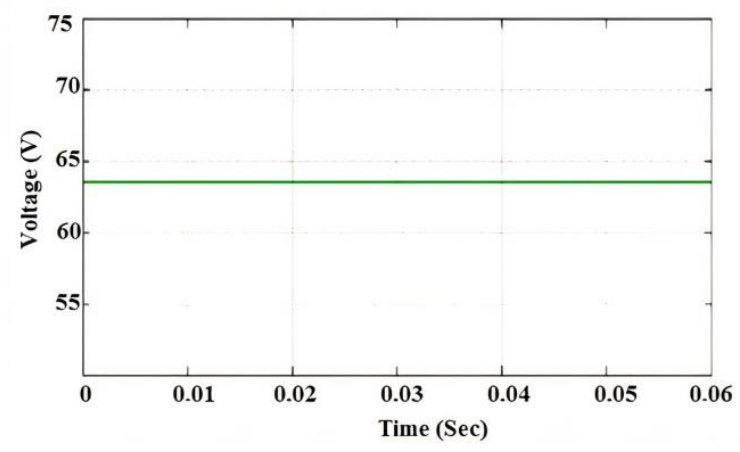

Fig.21. Solar PV voltage waveform.

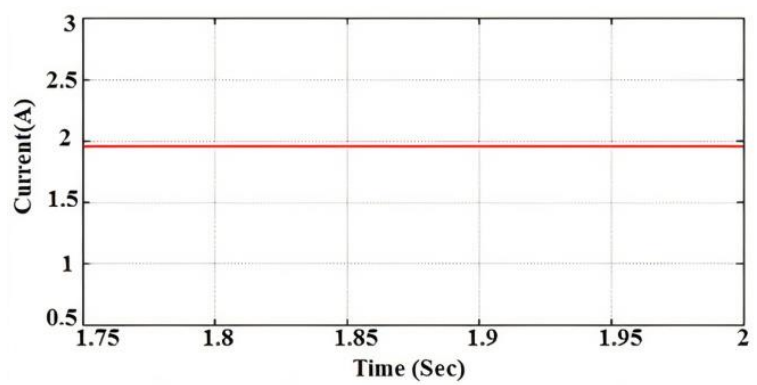

Fig.22. Solar PV output current waveform.

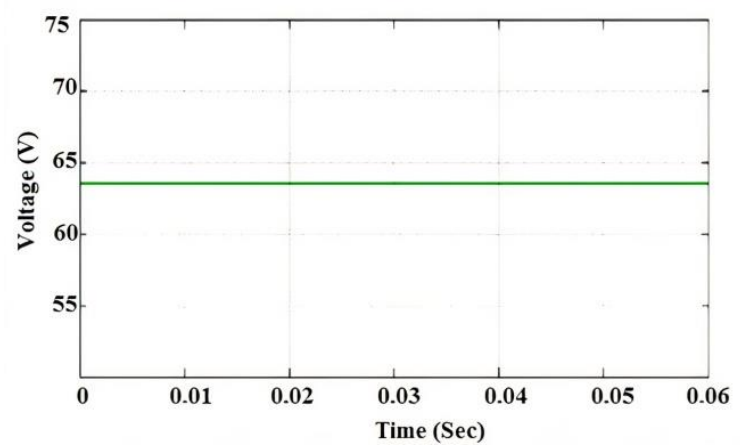

Fig.23. DC link voltage for PV with battery.

The PI control signal is not directly given to the inverter, instead it sends control signal to the PWM generator, which generates suitable PWM pulses for the inverter.

The FFT analysis for interleaved boost converter fed inverter tied micro gridis shown in fig. 26. The respective grid voltage and current waveform are depicted in figs. 27 and 28 respectively.

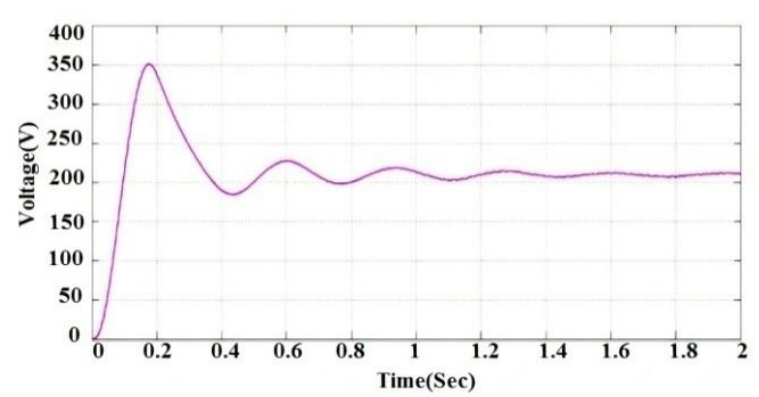

Fig.24. Boosted output voltage waveform.

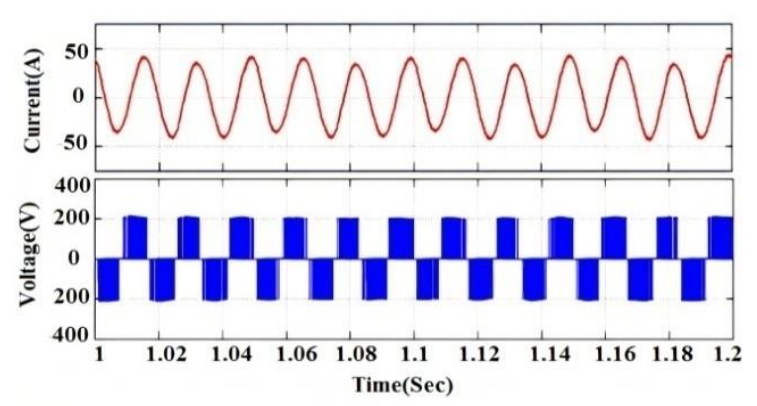

Fig.25. Voltage - current output waveform for PV with Battery.

The wind power is generated as AC quantity which is converted into DC and fed to the DC bus. The solar PV output is DC which is connected to the DC bus through a PI controller. The DC power is again converted into $\mathrm{AC}$ and fed to the grid through a voltage source converter. Once the grid current and voltage waveforms are obtained, the total harmonic distortion is measured and analyzed. The THD for the voltage waveform is shown in Figure 26.

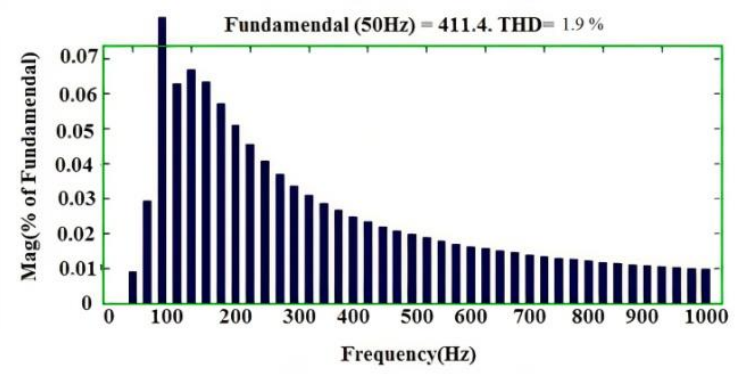

Fig.26. FFT analysis for interleaved boost converter fed inverter tied micro grid.

In order to prove the effectiveness of the proposed intelligent grid, again the total harmonic distortion is calculated for the three phase output current and voltage waveforms. Which is shown in Figure 27 and figure 28.

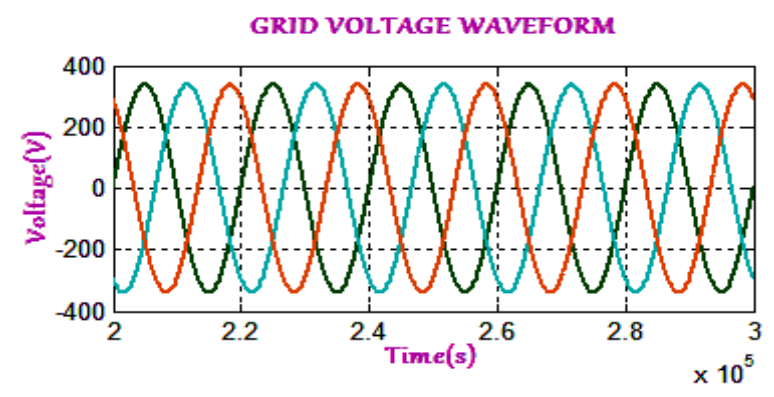

Fig. 27. Grid voltage waveform. 


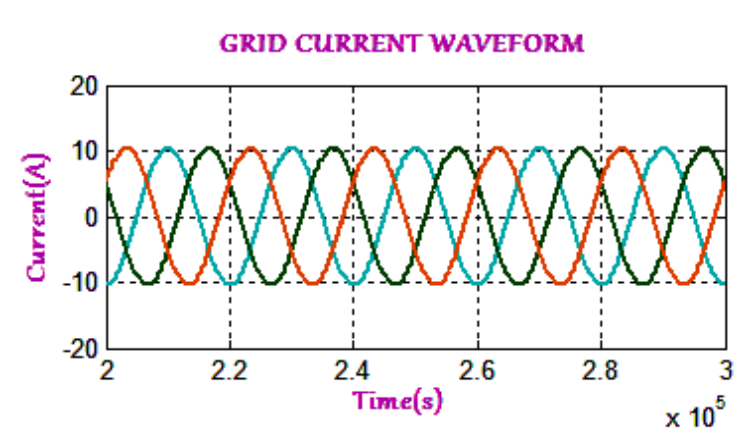

Fig. 28. Grid current waveform.

It is noted that the developed HRES system has significantly low grid current THD only if fuzzy based MPPT algorithm is assigned to the boost converter. Since the fuzzy MPPT control algorithm is AI based, it gives better result with less THD value, whereas the boost converter with classical MPPT algorithms have comparatively high THD value. The performance parameters of different algorithms of rise time, settling time, output power, ripple and efficiency are shown in table 3(a) and (3(b).

\section{OBSERVATION}

1. The proposed controller model, which control the wind and solar hybrid power system are power quality and voltage stability.

2. The non isolated dc to dc converters are also connected in this system, and at the grid side inverter is connected for changing dc to ac. The power is controlled in the system by the help of fuzzy logic controller. The Fuzzy logic controller reliable and stable.

Table 3(a): Performance parameters of different algorithms.

\begin{tabular}{|c|c|c|c|c|c|c|c|c|c|c|c|c|}
\hline \multirow{2}{*}{$\begin{array}{c}\text { Input } \\
\text { power } \\
\text { (W) }\end{array}$} & \multicolumn{4}{|c|}{ Rise time (s) } & \multicolumn{4}{|c|}{ Settling time } & \multicolumn{4}{|c|}{ Output power } \\
\hline & $\mathrm{P} \& \mathrm{O}$ & INC & INR & Fuzzy & $\mathrm{P} \& \mathrm{O}$ & INC & INR & Fuzzy & $\mathrm{P} \& \mathrm{O}$ & INC & INR & Fuzzy \\
\hline 100 & 0.54 & 0.52 & 0.48 & 0.42 & 0.56 & 0.54 & 0.49 & 0.43 & 91.22 & 93.43 & 95.95 & 97.35 \\
\hline 200 & 0.73 & 0.7 & 0.68 & 0.66 & 0.76 & 0.72 & 0.71 & 0.67 & 182 & 186.2 & 189.4 & 191.6 \\
\hline 300 & 1.32 & 1.22 & 1.2 & 0.95 & 1.35 & 1.25 & 1.23 & 0.96 & 270.75 & 278.1 & 282 & 289.2 \\
\hline 400 & 1.53 & 1.47 & 1.43 & 1.2 & 1.55 & 1.48 & 1.44 & 1.22 & 360.4 & 368.4 & 376 & 378.4 \\
\hline 500 & 1.72 & 1.64 & 1.63 & 1.5 & 1.76 & 1.67 & 1.64 & 1.54 & 447.7 & 453.5 & 467.5 & 475.5 \\
\hline
\end{tabular}

Table 3(b): Performance parameters of different algorithms.

\begin{tabular}{|c|c|c|c|c|c|c|c|c|}
\hline \multirow{2}{*}{$\begin{array}{c}\text { Input } \\
\text { power (W) }\end{array}$} & \multicolumn{4}{|c|}{ Ripple } & \multicolumn{4}{c|}{ Efficiency } \\
\cline { 2 - 10 } & P\&O & INC & INR & Fuzzy & P\&O & INC & INR & Fuzzy \\
\hline 100 & 4.75 & 4.5 & 3.17 & 0.25 & 91.22 & 93.4 & 96 & 97.35 \\
\hline 200 & 5.66 & 5.2 & 5.05 & 1.72 & 91 & 93.1 & 94.7 & 95.8 \\
\hline 300 & 6.22 & 5.9 & 5.7 & 4 & 90.25 & 92.7 & 94.4 & 95.3 \\
\hline 400 & 7.3 & 6.9 & 6.5 & 5.2 & 90.1 & 92.1 & 93.8 & 94.6 \\
\hline 500 & 8.1 & 7.7 & 7.2 & 6.1 & 89.4 & 90.7 & 93 & 94.1 \\
\hline
\end{tabular}

3. The proposed model, The MPPT used in solar5. energy gives the control signal to the dc to dc converter and these controlled outputs is given to6. the grid or to the load.

Similarly for wind energy also maximum power point tracking is used for getting maximum power by controlling wind speed

4. By using synchronous reference frame the reference current for hysteresis controller is obtained. The hybrid controllers are not only used for controlling harmonics and also for compensating positive and negative sequence reactive power.

The reactive power is maintained at zero level in order to ensure the unity power factor operation.

The system for a strong interconnection grid system, the performance of the controller is much better and faster as compared to that for a weak interconnected grid system.

While implementing the practical consequences, there will be a ripple current significant rise whenever the inverter feeds non-linear load, and its majority of concern is magnetizing current. 


\section{CONCLUSION}

The performance evaluation of isolated micro grid with hybrid renewable generation system is was implemented in MATLAB/SIMULINK background.

Hybrid power generation systems tied micro grid are analyzed for non isolated DC-DC converter with fuzzy logic ontrol strategies. The dynamic behavior of DC-DC boost converter fed with PV source is considered and the related characteristics improve the converter's stability range.

The incorporated three-phase grid synchronization injects the power generated to the grid with the compensation of reactive power and harmonics. The voltage obtained from wind and

\section{References}

[1] Mbungu, Nsilulu T., Ramesh C. Bansal, Raj Naidoo, V. Miranda, and M. Bipath, (2018). "An optimal energy management system for a commercial building with renewable energy generation under real-time electricity prices", Sustainable cities and society 41, 392404.DOI:https://doi.org/10.1016/j.scs.2018.05.049

[2] Elavarasan, Rajvikram Madurai, Shafiullah G. M., Sanjeevikumar Padmanaban, Nallapaneni Manoj Kumar, Annapurna Annam, Ajayragavan Manavalanagar Vetrichelvan, Lucian Mihet-Popa, and Jens Bo Holm-Nielsen. (2020). "A comprehensive review on renewable energy development, challenges, and policies of leading Indian states with an international perspective", IEEE Access, 8, 74432-74457. DOI: https://doi.org/10.1109/ACCESS.2020.2988011

[3] Junzhi Yu;Chunxia Dou, Xinbin Li. (2016). "MAS-Based Energy Management Strategies for a Hybrid Energy Generation System", IEEE Transactions on Industrial Electronics, 63(6), 37563764..DOI:https://doi.org/10.1109/TIE.2016 .2524411

[4] Ranjay Singh, Ramesh C. Bansal, Arvind R. Singh, Raj Naidoo. (2018). "Multi-Objective Optimization of Hybrid Renewable Energy System Using Reformed Electric System Cascade Analysis for Islanding and Grid Connected Modes of Operation”, IEEE Access, 6, pp 47332 47354..URI: http://hdl.handle.net/2263/67398

[5] Ligade Gitanjali Vasant, V. R. Pawar. (2017). "Solar-wind hybrid energy system using MPPT", 2017 International Conference on Intelligent Computing and Control Systems (ICICCS), 8.

[6] Olubayo Moses Babatunde, Josiah Lange Munda;Yskandar Hamam. (2020). "A Comprehensive State-of-the-Art Survey on Hybrid Renewable Energy System Operations and solar is about 120 volt, which is increased to about 600 volt by using interleaved boost converter. This clearly shows that for hybrid power generation systems fed interleaved boost converter is the promising combination for inverter tied micro grid and also interleaved boost converter have fewer harmonic compared to fly back converter.

Due to less harmonic distortion of interleaved boost converter the efficiency of hybrid renewable energy, tied micro grid is increased and the results obtained indicate improved performance with minimized THD of $1.9 \%$.

Planning”, IEEE Access, 8, 75313 75346..DOI:10.1109/ACCESS.2020.2988397

[7] Saptarshi De, Gnana Swathika, O. V., Nilanjan Tewari, Anantha Krishnan Venkatesan, Umashankar Subramaniam, Mahajan Sagar Bhaskar, Sanjeevikumar Padmanaban, Zbigniew Leonowicz, Massimo Mitolo. (2020). "Implementation of Designed PV Integrated Controlled Converter System”, IEEE Access, 8, 100905 - 100915.10.1109/ ACCESS.2020.2997405

[8] Md Waseem Ahmad, Naga Brahmendra Yadav Gorla, Hasmat Malik, Sanjib Kumar Panda. (2021). "A Fault Diagnosis and Postfault Reconfiguration Scheme for Interleaved Boost Converter in PV-Based System", IEEE Transactions on Power Electronics, 36(4), 3769 3780.DOI:https://doi.org/10.1109/TPEL.2020.30 18540

[9] Raghavendra, Kummara Venkat Guru, Kamran Zeb, Anand Muthusamy, T. N. V. Krishna, Kumar S. V. S., Do-Hyun Kim, Min-Soo Kim, Hwan-Gyu Cho, and Hee-Je Kim. (2020). "A comprehensive review of $D C-D C$ converter topologies and modulation strategies with recent advances in solar photovoltaic systems", Electronics, 9(1), 31. DOI: https://doi.org/10.3390/electronics9010031

[10] Hossain, M. Z., and Rahim, N. A. (2018) "Recent progress and development on power DC-DC converter topology, control, design and applications: A review", Renewable and Sustainable Energy Reviews, 81, pp: 205230.DOI:10.1016/j.rser.2017.07.017

[11] Ratnakar Babu Bollipo, Suresh Mikkili, Praveen Kumar Bonthagorla, (2021). "Hybrid, optimal, intelligent and classical PV MPPT techniques: A review", CSEE Journal of Power and Energy Systems,7,9-33.DOI:10.17775/CSEEJPES.2019.027 
[12] Saeed H. Hanzaei, Saman A. Gorji, Mehran Ektesabi. (2020). "A Scheme-Based Review of MPPT Techniques With Respect to Input

[13] Amjad Ali, Khalid Almutairi, Sanjeevikumar Padmanaban, Vineet Tirth, Salem Algarni Kashif Irshad;Saiful Islam, Md. Hasan Zahir, Md. Shafiullah, Muhammad Zeeshan Malik. (2020). "Investigation of MPPT Techniques under Uniform and Non-Uniform Solar Irradiation Condition-A Retrospection", IEEE Access, 8, 127368127392.DOI:10.1109/ACCESS.2020.302850

[14] Mahmoud Dhimish. (2019). "Assessing MPPT Techniques on Hot-Spotted and Partially Shaded Photovoltaic Modules: Comprehensive Review Based on Experimental Data", IEEE Transactions on Electron Devices, 66(3), 1132 - 1144.

[15] Shoaib, Muhammad, Imran Siddiqui, Shafiqur Rehman, Shamim Khan, and Luai Alhems, M. (2019). "Assessment of wind energy potential using wind energy conversion system", Journal of cleaner production, 216, 346-360.

[16] Bensalah, Benhamida, A., M. A., Barakat G. and Amara, Y. (2018). "Large wind turbine generators: State-of-the-art review”, In 2018 XIII International Conference on Electrical Machines (ICEM), IEEE, 2205-2211.

\section{Information about authors.}

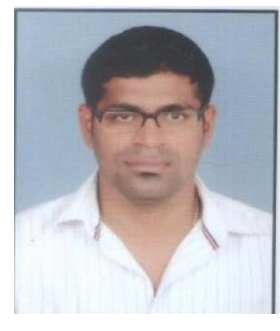

Sathish. CH, Research Scholar \& Assistant Professor, Department of Electrical and Electronics Engineering, Annamalai University, Tamilnadu, India 608002. Field of scientific interest is Power Distribution System. E-mail: anusmin2@gmail.com



Chidambram I.A. Ph.D Professor, Department of Electrical and Electronics Engineering. Annamalai University, Tamilnadu, India 608002. Field of scientific interest is Power Quality in Electrical Distribution systems,E-mail: driacdm@gmail.com
Variables Including Solar Irradiance and $P V$ Arrays' Temperature", IEEE Access, Volume: 8, pp:182229-182239.DOI:10.1109/ACCESS.2020.3028580.

[17] Ifte Khairul Amin and Mohammad Nasir Uddin. (2020). "Nonlinear Control Operation of DFIGBased WECS Incorporated With Machine Loss Reduction Scheme", IEEE Transactions on Power Electronics, 35(7), 7031 - 7044.

[18] Nikolaos Jabbour, Evangelos Tsioumas, Christos Mademlis, Evgeny Solomin, (2020). "A Highly Effective Fault-Ride-Through Strategy for a Wind Energy Conversion System with a Doubly Fed Induction Generator", IEEE Transactions on Power Electronics, 35(8), 8154 - 8164.

[19]Elsie F. Swana, Wesley Doorsamy. (2019). "Investigation of Combined Electrical Modalities for Fault Diagnosis on a Wound-Rotor Induction Generator", IEEE Transactions on Power Electronics, 7, 32333 - 32342.

[20]Attapong Mamen, Uthane Supatti. (2017). "A survey of hybrid energy storage systems applied for intermittent renewable energy systems ", 2017 14th International Conference on Electrical Engineering/Electronics, Computer, Telecommunications and Information Technology (ECTI-CON).

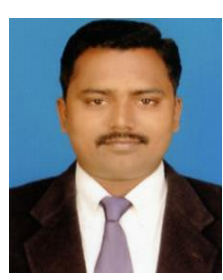

Manikandan. M, Ph.D, Professor, Department of Electrical and Electronics Engineering. Jyothishmatthish Institute of Technology and Science, Telangana, India- 505481 Field of scientific interest is Power Quality in Electrical Distribution systems,

E-mail: cm.manikandan@gmail.com 